\title{
Thallium, Nickel, Cobalt and Other Trace Elements in Iron Sulfides from Belgian Lead-Zinc Vein Deposits
}

\author{
J. C. Duchesne ${ }^{1}$, A. Rouhart ${ }^{1}$, C. Schoumacher ${ }^{1}$ and H. Dillen ${ }^{2}$ \\ 1 Laboratoires associés de Géologie, Pétrologie et Géochimie, Université de Liège, Sart Tilman, Belgique \\ 2 Departement Scheikunde, Universitaire Instelling Antwerpen, Wilrijk, Belgie
}

\begin{abstract}
Fe-sulfides associated with Belgian $\mathrm{Pb}-\mathrm{Zn}$ vein deposits have been analysed by $\mathrm{DC}$ arc spectrometry and XRF for $\mathrm{Tl}, \mathrm{Ni}, \mathrm{Co}, \mathrm{Mn}, \mathrm{Zn}, \mathrm{Pb}, \mathrm{Ge}, \mathrm{Cd}$, and As. They show high T1 contents (from $>30 \mathrm{ppm}$ upt to $6800 \mathrm{ppm}$ ) and Co:Ni ratios < 1 . These features permit to distinguish them from Fe-sulfides of sedimentary and high temperature occurrences. The Tl distribution in a botryoidal marcasite of Vedrin (average Tl content of $0.68 \%$ ) has been investigated by ion microprobe. It displays a pattern similar to colloform texture. Principal component analysis shows that the behaviour of $\mathrm{T} 1$ is partly controlled by a factor opposing $\mathrm{T} 1$ to all other elements. This is interpreted as reflecting the influence of sorption mechanisms by contrast with direct precipitation. T1 and the other elements are not considered of magmatic origin because no acidic magmatism is known during or after Variscan times. Extraction from sedimentary rocks by hydrothermal brines is favoured.
\end{abstract}

\section{INTRODUCTION}

A systematic study of the trace element geochemistry of pyrite and marcasite has been undertaken in order to characterized iron sulfides associated with $\mathrm{Pb}-\mathrm{Zn}$ vein deposits, and to examine whether trace elements could help to understand the conditions of formation of the ore, and thus facilitate the detection of hidden deposits. A preliminary study by Duchesne (1964) showed the presence of relatively large amounts of thallium in marcasite from the Vedrin ore deposit (Belgium) and pointed to the similarities with $\mathrm{Pb}-\mathrm{Zn}$ deposits from the Cevennes border in France. The purely syngenetic origin of these latter deposits proposed by Bernard (1961) was questioned on this basis (Duchesne,
1964), and discussed (Bernard, 1965; Duchesne, 1965). The present study corroborates these first results with the help of more powerful analytical techniques and statistical methods of interpretation.

\section{ANALYTICAL METHODS}

As a general rule, the specimens were carefully investigated under the reflected Iight microscope to select the homogeneous Fe-sulfide parts of the ore. The purity of the sampled parts was checked under the binocular after reduction to sma11 fragments. When necessary hand-picking of impurities was further done and remains of calcite removed by a brief HCl $2 \mathrm{~N}$ attack. Though greatest care was exercised in the ope- 
ration, the method - like any other separation method - cannot however warrant the absolute purity of the analysed aliquots of the samples. This fact was taken into consideration in the interpretation of data by means of statistical methods (see below). The use of Clerici's solution (T1 formate and malonate) as a density liquid has been prohibited to avoid contamination by $\mathrm{T} 1$. The final grinding to about -150 mesh was done in agate mortars.

Three different analytical methods are used:

\section{DC arc spectrography}

2. X-ray fluorescence spectrometry

3. Ion microprobe analysis (SIMS)

1. DC arc spectrography is used to determine $\mathrm{Co}, \mathrm{Ni}, \mathrm{Mn}, \mathrm{Cd}, \mathrm{Ge}, \mathrm{Sb}, \mathrm{Bi}, \mathrm{Sn}$, $\mathrm{Cr}$ as well as low contents of $\mathrm{Tl}, \mathrm{Pb}$ and As. The method is inspired from Hegemann and Leybold (1954). The powdered sample is mixed with 2 parts of "specpure" graphite, and loaded in the conical cavity of a graphite electrode (SCHRIBNER type - National Carbide L4024). A $3 \mathrm{~mm}$ diam-rod (Le CarboneLorraine type 207) is used as an upper electrode. A drop of Elvacite 2044 diluted in toluene is placed on the loaded electrode and dried in order to form a cake. This procedure prevents loss of material during the first seconds of arcing and regularizes burning. An optimum reproductibility $( \pm 5 \%)$ can thus be obtained.

A stabilized DC arc of $6.5 \mathrm{~A}$ and $220 \mathrm{~V}$ from a PHILIPS Multisource is used to burn the sample (anode) during $30 \mathrm{sec}$. All analyses are duplicated. The spectrograph is a FUESS $110 \mathrm{H}$ (4 prisms) equivalent to the HILGER large spectrograph. The densitometer is mod $\mathrm{C}$ 1285 from FUESS. The spectra are recorded on KODAK plates (type) SA 1 in the range of $2760 \AA$ to $3480 \AA$. The analytical lines ( $)$ are the following: Co 3044; Ni 3051; Mn 2933; Zn 3822; Cd 3261 ; Cu 3274; Ge 3039; Sb 3878; Bi 3068 ; Sn 2840; Cr 3015; T1 2768; As 2780; Fe 3053 is used as an internal standard. Four international standard samples of pyrite: PS-1 (Schrön et a1., 1975), P-1 and P-2 (Robinson and Walshe, 1977) and ASK-3 (Christie, 1975) are used for calibration of $\mathrm{Co}, \mathrm{Ni}, \mathrm{Mn}, \mathrm{Zn}, \mathrm{Cu}$. The four standards provide excellent working curves for $\mathrm{Co}, \mathrm{Ni}, \mathrm{Mn}$ and $\mathrm{Zn}$, and a good one for $\mathrm{Cu}$. Only one standard out of the four available can be used for $\mathrm{Cd}, \mathrm{Ag}, \mathrm{Sb}, \mathrm{Bi}, \mathrm{Sn}$ and $\mathrm{Cr}$. Therefore, $45^{\circ}$ slope working curves, passing through the standard values, in loglog coordinates, are used for these elements (Ahrens and Taylor, 1961). For Ge synthetic standards obtained by mixing $\mathrm{Ge}$ to $\mathrm{F}_{2} \mathrm{O}_{3}$ matrix are used. $\mathrm{T} 1$, $\mathrm{Pb}$ and $\mathrm{As}$ are calibrated with values measured by $X$-ray fluorescence. The detection limits are: $0.2 \mathrm{ppm} \mathrm{Ag} ; 1 \mathrm{ppm}$ $\mathrm{Pb}, \mathrm{Mn}, \mathrm{Cu}, \mathrm{Ge} ; 5$ ppm $\mathrm{Co}, \mathrm{Ni}, \mathrm{Sb}, \mathrm{Bi}$, $\mathrm{Sn}, \mathrm{Cr} ; 10 \mathrm{ppm} \mathrm{T1} ; 15 \mathrm{ppm} \mathrm{As,} \mathrm{Cd}$.

2. X-ray fluorescence analysis is used for the determination of relatively high contents of $\mathrm{T} 1, \mathrm{~Pb}$ and As. A CGR a1pha 2020 semi-automatic spectrometer working with a Mo-tube at $50 \mathrm{kV}$ and $50 \mathrm{~mA}$ and a LiF 100 analysing crystal is used. Analytical lines are $\mathrm{T} 1 \mathrm{~L} \beta_{1}$, As $K \beta_{1}$ and $\mathrm{Pb} \mathrm{L} \beta_{1}$. Standard samples ASK -3 and $P S-1$ are used to calibrate the method for $\mathrm{Pb}$ and As. Synthetic samples made by mixing various amounts of $\mathrm{Tl}_{2} \mathrm{O}_{3}$ to a pyritic matrix are used for T1. It must be noted that the T1 content of $100 \mathrm{ppm}$, given by Schrön et al. (1975) for PS-1, is highly overestimated. No T1 is detected by $\mathrm{DC}$ arc spectrography, which means that the T1 content is lower than $10 \mathrm{ppm}$. Inspection of the most sensitive line at 5350 \& with ICP spectrography also reveals no T1. The limits of detection (LD), following Currie (1968), are 30 $\mathrm{ppm} \mathrm{Tl}$ and $\mathrm{Pb}$ and $45 \mathrm{ppm}$ As.

3. Secondary ion mass spectrometry (SIMS) in the ion microscope mode is used to study the distribution pattern of $\mathrm{Tl}$ through polished sections of about $1 \mathrm{~cm}$ in diameter, with a spatial resolution of 1-10 $\mu \mathrm{m}$. Quantitative analyses with a spatial resolution of $250 \mu \mathrm{m}$ is possible for e.g. Mn, Co, $\mathrm{Ni}, \mathrm{Cu}$ and $\mathrm{T} 1$. The instrument used is a Cameca IMS; 300 ion microscope, and a $6 \mathrm{KeV} \mathrm{Ar}^{+}$ primary beam is used with a current density of $12 \mathrm{~A} / \mathrm{mm}^{2}$. For quantitative ana1yses an electrostatic sector is used to select $140-160 \mathrm{eV}$ ions for $\mathrm{Mn}$, Co, $\mathrm{Ni}$ and $\mathrm{Cu}$, and $60-80 \mathrm{eV}$ ions for $\mathrm{T} 1$. The analysed surface is $250 \mu \mathrm{m}$ in diameter. 
For calibration of $\mathrm{Mn}$, $\mathrm{Co}$ and $\mathrm{Cu}$ the four already mentioned reference samples are used in the form of pellets, as described by Dillen and Gijbels (1981). No certified standards being available for quantitative T1 analyses, a sample from Vedrin, which has been examined by SIMS and found virtually homogeneous at the $250 \mu \mathrm{m}$-scale (standard deviation for 14 different measuring sites of $250 \mu \mathrm{m}$ diameter each: $11 \%$ ), is used as a reference sample after determination of its Tl content by ICP-AES, in nitric acid solution, using the 5350 \& Tl-1ine. The instrument is calibrated by $\mathrm{Tl}$-solutions containing the same amount of iron and acids. A concentration of 6800 $\mathrm{ppm}$ is found by that method for the Vedrin sample. A massive part of the specimen is used to determine a sensitivity factor for SIMS, with ${ }^{32} \mathrm{~S}$ as an internal standard.

\section{SAMPLING}

84 samples belonging to 36 occurrences of marcasite or pyrite have been anal-

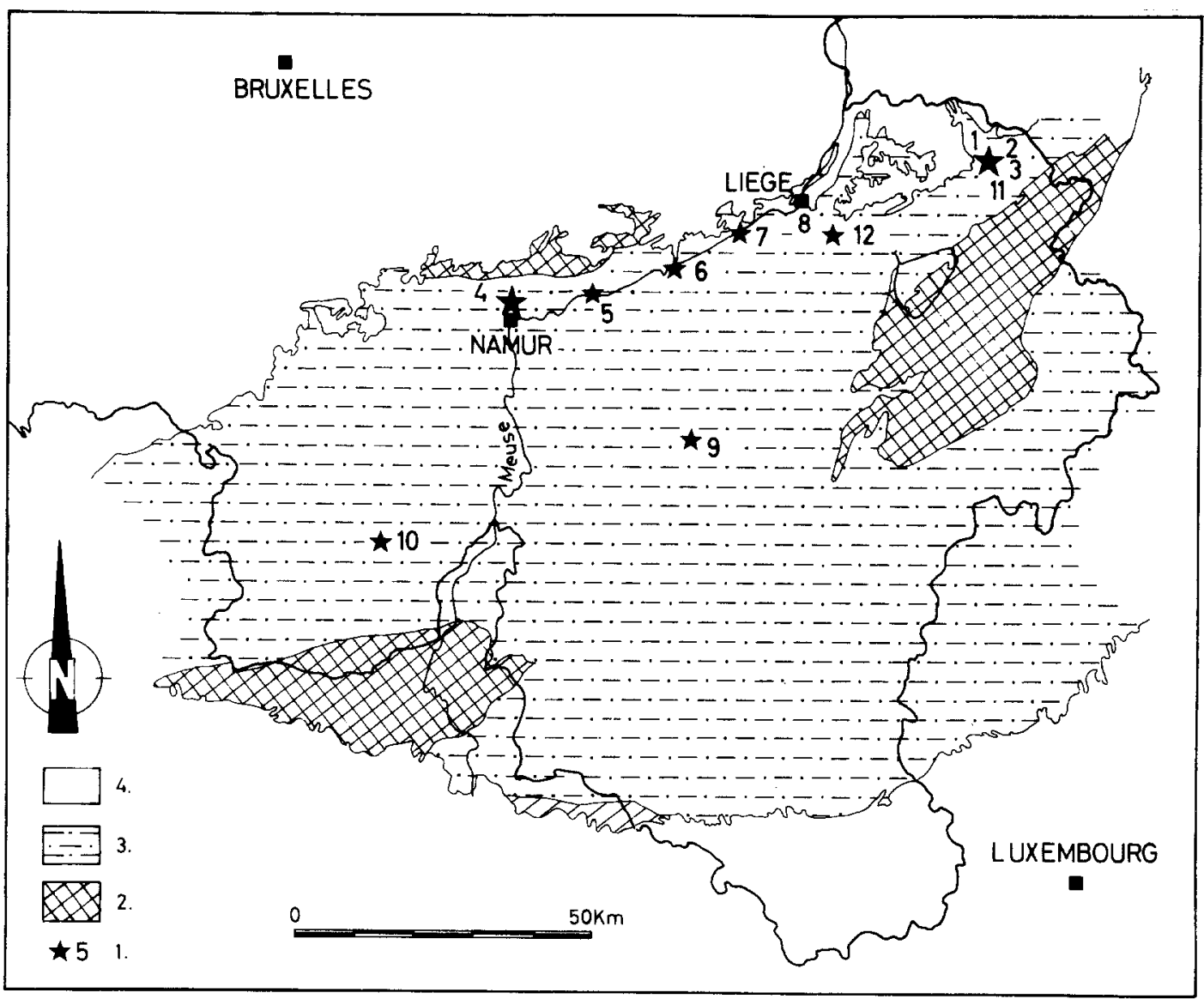

Fig. 1. Geological sketch map of South Belgium showing the provenance of the various iron sulfide samples from $\mathrm{Pb}-\mathrm{Zn}$ vein deposits. 4. Post-Variscan terrains; 3 . Devonian and Carboniferous terrains; 2. Cambrian and Silurian terrains; 1 . Numbered stars refer to the investigated occurrences: $1,2,3$ and 11 : Poppelsberg, Stuck, Lontzen and Moresnet, respectively; 4: Vedrin; 5: HayesMonet; 6: Corphalie; 7: Engis; 8: Angleur; 9: Heure; 10: Villers-en-Fagnes; 12: Chaudfontaine 
ysed. The main occurrences come from East Belgium (Fig. 1): Poppelsberg

(11 samples) and Stuck (2 samples) are small post-Variscan $\mathrm{Pb}-\mathrm{Zn}$ vein deposits cutting across Dinantian carbonate rocks and Famennian rocks of the Vesdre Massif. They were recently drilled by the Union Minière Company. Lontzen (15 samples) also belongs to the same type of mineralization and comes from the same area, but is entirely situated in siltic to pelitic rocks of Famennian age.

Another well documented site - the Vedrin Mine, near Namur - has also been investigated. It is a vein deposit in Dinantian carbonate rocks of the Namur synclinorium (Evrard, 1943). Two types of sulfides are studied. The first and most common one is the vein type (12 samples): a fibro-radiated marcasite associated with some blende and galena in a calcite gangue. The second type (5 samples) is a marcasite, filling small veins and veinlets of a brecciated dolostone, at a distance of 10-20 m from the main vein.

other Belgian $\mathrm{Pb}-\mathrm{Zn}$ occurrences have also been included: Hayes-Monet, Corphalie, Engis and Angleur (2 samples) from the Namur synclinorium; Heure and Villers-en-Fagnes in Devonian strata from the Dinant synclinorium; Moresnet and Chaudfontaine in the Vesdre Massif, the latter is a cubic pyrite associated with a baryte stratiform deposit (Dejonghe, 1979) in Devonian strata.

Two occurrences from the Cévennes border - Soulier and St Félix de Pallière - previously studied by Duchesne (1964) have also been reinvestigated.

Moreover, 12 .occurrences from sedimentary rocks, mainly pyrite cubes from shales, have been included for the sake of comparison (Rochelinva1, Bayehon, Deville, Grand-Halleux, Longfaye, Huccorgne, Ronquière, Grufflingen, Bouxharmont, Visé, Gris-Nez - France, Ballachullish - Scotland) as well as pyrites formed at high temperature (AgrokipiaCyprus, Calamita and Rio Marine - I. E1ba, Pamour-Canada, Luzenac-France and Buranga-Ruanda).

The results of the analysis are summarized in Table 1 which gives the average and the range of variation of each trace element in each occurrence.
DISCUSSION

The results usually show a wide dispersion in the various $\mathrm{Pb}-\mathrm{Zn}$ occurrences. They can however be summarized as follows:

1. The Co content is low - usually close to or below $5 \mathrm{ppm}$ - in the Belgian $\mathrm{Pb}-$ $\mathrm{Zn}$ type and contrasts with the sedimentary and high temperatures occurrences, which show averages of $332 \mathrm{ppm}$ and 2180 $\mathrm{ppm}$ respectively. The Ni content of the $\mathrm{Pb}-\mathrm{Zn}$ type is higher than the $\mathrm{Co}$ and can be compared to the sedimentary or high temperature sulfides. Therefore, the $\mathrm{Co}: \mathrm{Ni}$ ratio is $<1$ in the $\mathrm{Pb}-\mathrm{Zn}$ type. According to classical interpretations (see e.g. the reviews by LoftusHills and Solomon, 1967 and Bralia et al., 1979) this would indicate a sedimentary origin. However, the various authors usually consider that this criterion is poorly significant when used alone. The present data on sedimentary occurrences also confirm that the $\mathrm{Co} / \mathrm{Ni}$ ratio has to be used with caution. Indeed, 5 out of 12 sedimentary occurrences which are studied here show $\mathrm{Co}: \mathrm{Ni}>1$, an inverse relation to what should be expected since they all concern typical cubic pyrites in black shales or slates. It is likely that recrystallization due to incipient metamorphism can lead to an enrichment of Co with respect to $\mathrm{Ni}$, in such a way that an original $\mathrm{Co}: \mathrm{Ni}<1$ might be modified to a $\mathrm{Co}: \mathrm{Ni}>1$.

It can be concluded that, in $\mathrm{Pb}-\mathrm{Zn}$ deposits, the $\mathrm{Co}: \mathrm{Ni}$ ratio in iron sulfides has no genetic significance since the observed relation $(<1)$ is not in agreement with the geological evidence. It must however be noted that the low Co content of the $\mathrm{Pb}-\mathrm{Zn}$ occurrences appears to be a feature restricted to this type of deposits and is likely to have a promising genetic meaning.

2. Thallium is always present (from $>30 \mathrm{ppm}$ up to $6800 \mathrm{ppm}$ ) in the Belgian $\mathrm{Pb}-\mathrm{Zn}$ type, whatever the geological unit to which they belong (Dinant or Namur synclinoria, Vesdre Massif) or the age of the enclosing rocks (Dinantian or Devonian). It is also present in the Cevennes border (Duchesne, 1964) where Aubagne and Leleu (1981) have recently 


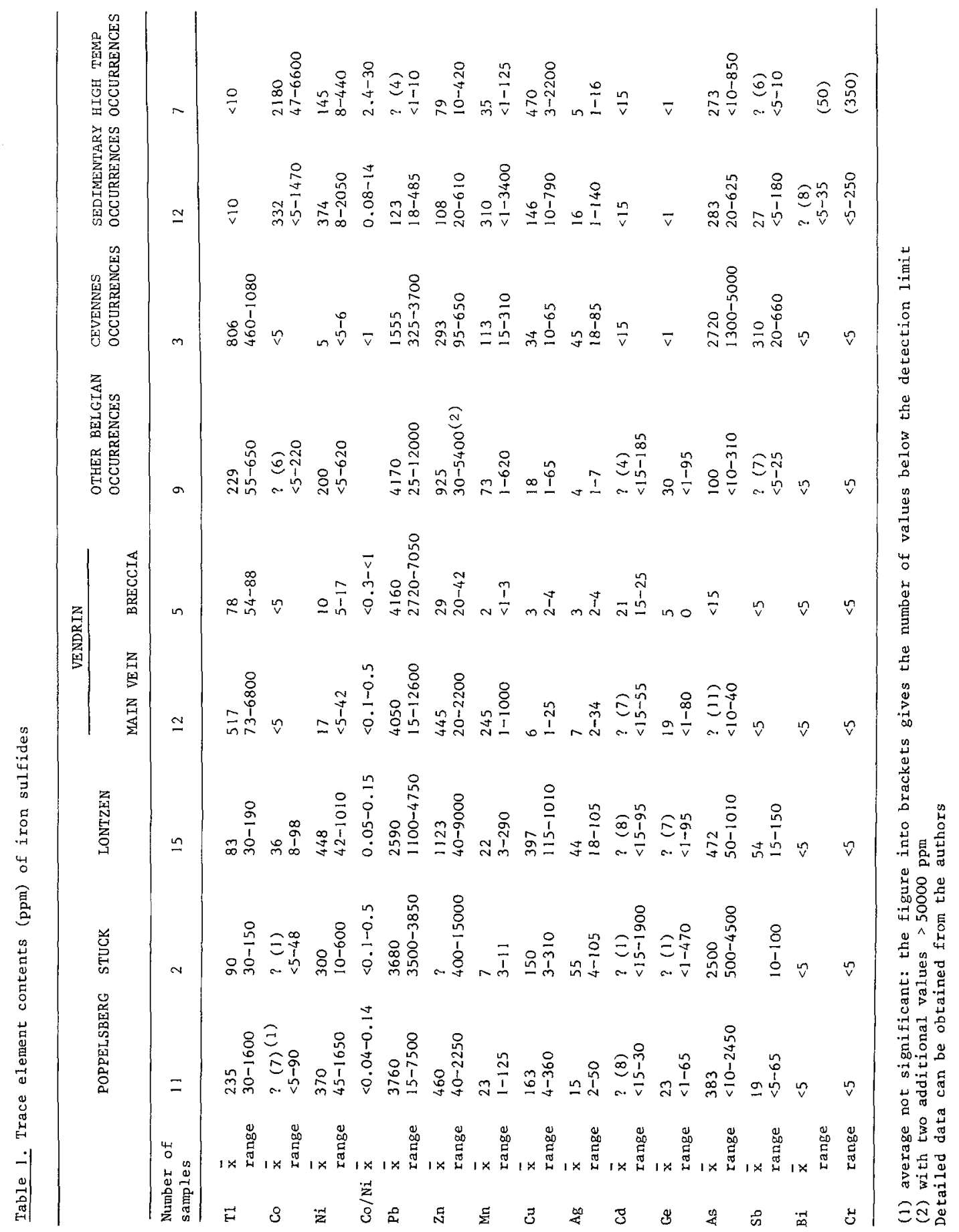


mentioned $\mathrm{T} 1$-rich $(0,5$ to $1 \%)$ melnikovites and marcasites in Pallière.

On the other hand, T1 is absent $(<10 \mathrm{ppm})$ from all sedimentary and high temperature occurrences. According to Ivanov et al. (1960), Tl is commonly found in numerous varieties of polymetallic deposits. It is usually more enriched in sphalerite or galena than in iron sulfides, e.g. from some Caucasus deposits. Shaw (1952) and Albuquerque and Shaw (1972) a1so report high T1 content in marcasite from several localities (Japan, Caucasus, Central Asia, etc...). In Western Europe, since Stoiber (1940), T1 is mentioned in $\mathrm{Pb}-\mathrm{Zn}$ deposits of Belgium, Westphalia, and Silesia. Except for the data of Thein (1975) on the Meggen deposit (see below), no modern analyses have been made available on sulfides and this hampers the study of the chalcophile behaviour of $\mathrm{T} 1$.

In the Belgian $\mathrm{Pb}-\mathrm{Zn}$ occurrences the maximum $\mathrm{T} 1$ content in iron sulfides is found in a radiated botryoidal marcasite from the Vedrin mine $(0,68 \%)$. The distribution of $\mathrm{T} 1$, as revealed under the ion microprobe, is shown on Plate 1. $\mathrm{T} 1$ is not incorporated as independent phases larger than $1 \mu \mathrm{m}$ (the resolution power of the ion microprobe) and can thus be considered regularly distributed troughout the marcasite phase. At a larger scale thin alternating bands (from 1 to $50 \mathrm{\mu m}$ ) of contrasting $\mathrm{T} 1$ contents are disposed perpendicular to the radiating directions of the texture. The overall picture is quite similar to the so-called colloform texture and can be put together with the fact that $\mathrm{T} 1$ is notably enriched in colloform varieties of iron sulfides (Ivanov et al., 1960). In a second specimen from Vedrin an inclusion of a $\mathrm{Tl}$ and $\mathrm{Pb}$ bearing mineral-possibly hutchinsonite $(\mathrm{Pb}, \mathrm{Tl})_{2}(\mathrm{Cu}, \mathrm{Ag}) \mathrm{As}_{5} \mathrm{~S}_{10}$ - was also found, thus indicating that trace minerals can also control the distribution of $\mathrm{T} 1$.

3 . Some variations can be observed between the different Belgian deposits or even within the same deposit. The Vedrin marcasites are low in $\mathrm{Co}$, $\mathrm{Ni}$, $\mathrm{As}, \mathrm{Sb}$, $\mathrm{Cu}, \mathrm{Ag}$ compared to the East Belgium occurrences. The $\mathrm{T} 1, \mathrm{Zn}, \mathrm{Mn}, \mathrm{Cu}$ and $\mathrm{Ag}$ contents in the Vedrin marcasite from the brecciated dolostone are lower than in the main vein occurrences; they also display less dispersed values. In Lontzen, almost all trace elements are enriched relative to the PoppelsbergStuck type. Since the deposits all belong to the same fault system, it is likely that this difference is due to the siltic to pelitic nature of the Famennian enclosing rocks at Lontzen as compared to the carbonate rocks at Poppelsberg and Stuck.

4. In addition to the variations between the different occurrences, the trace elements display large intervals of variation within the different deposits. In order to investigate these variations in detail, the statistical method of principal component analysis has been applied to the $\mathrm{Pb}-\mathrm{Zn}$ type. The computing has been performed by the Fortran IV program of Davis (1973) adapted for a Heathkit 289 microcomputer with a memory of $64 \mathrm{~K}$ of RAM and two 5.25 inch floppy discs.

Fig. 2 summarizes the results obtained on 40 samples from $\mathrm{Pb}-\mathrm{Zn}$ deposits, representing the whole population of this type except the samples from the Vedrin mine. $\mathrm{Bi}$ and $\mathrm{Cr}$ which are absent from the $\mathrm{Pb}-\mathrm{Zn}$ type were not considered. The reason for discarding the Vedrin samples is that the contents in $\mathrm{Co}, \mathrm{Cd}$, As and $\mathrm{Sb}$ are currently below the limit of detection of the method. A large number of data below the detection limit can indeed artificially modify the true correlation between the elements.

Four factors can explain 72 \% of the variance of the population. They can be interpreted as follows.

Factor 1 opposes T1 to a group of several elements which comprises elements such as $\mathrm{Ni}, \mathrm{Co}, \mathrm{Zn}, \mathrm{Cu}$ and $\mathrm{Ge}$ which have an ionic radius close to that of $\mathrm{Fe}$ and therefore are compatible with their entering in the crystallizing iron sulfide by isomorphism. On the other hand, the opposite sign of the T1 factor loading can indicate a different controlling mechanism, possib$1 y$ related to the higher value of the ionic radius $\left(\mathrm{T}^{+}=1.40 \AA\right.$ ) (Sahl, 1974). As already mentioned, $\mathrm{T} I$ is enriched in minerals presenting a collo- 


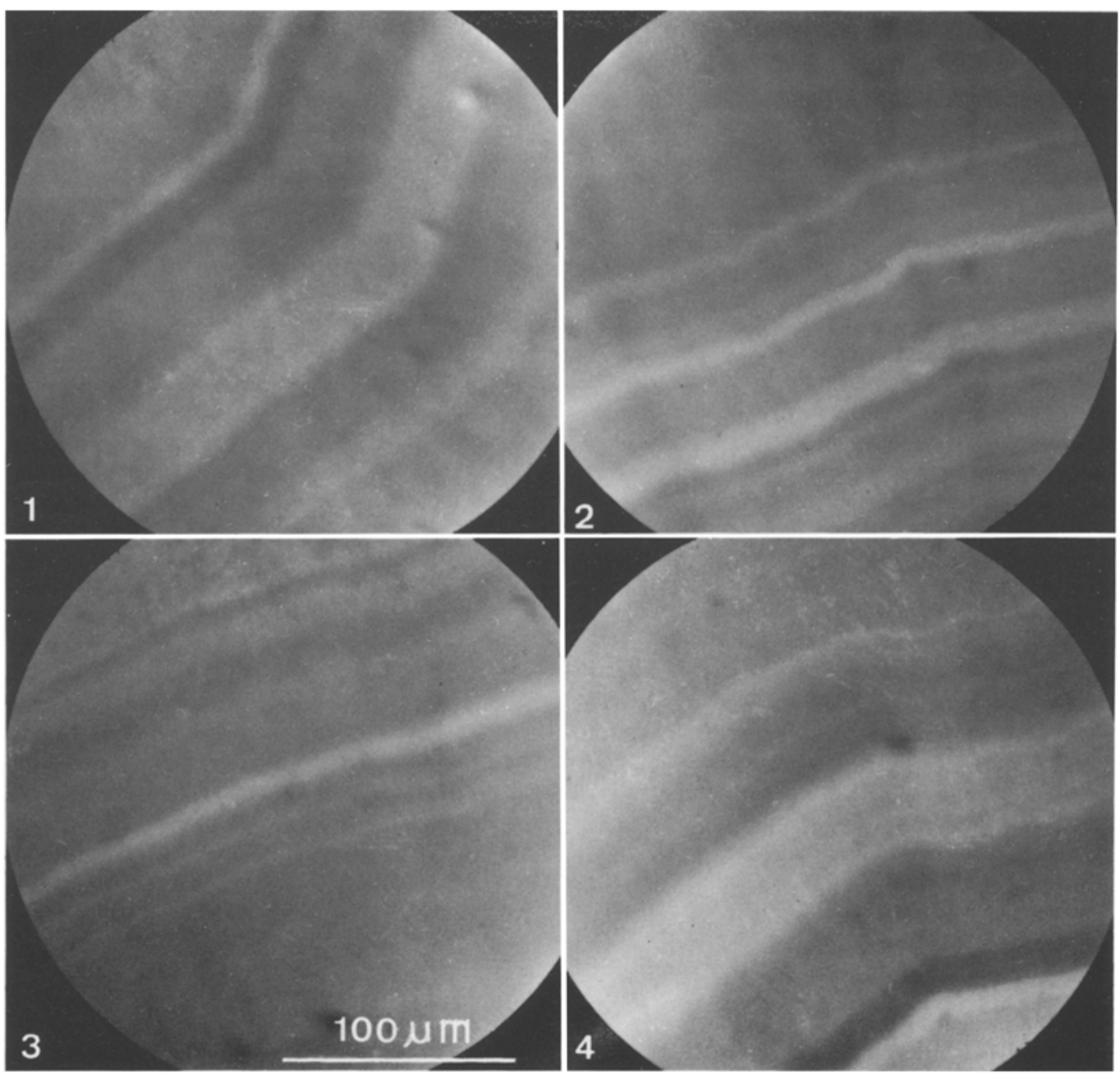

P1ate 1. T1 distribution in a botryoidal marcasite from the Vedrin mine (Namur, Belgium) as revealed by secondary ion mass spectrometry (ion microprobe). Thin alternating bands ( 1 to $50 \mu \mathrm{m}$ ) of contrasting Tl contents - the higher the content, the darker the intensity - are perpendicular to the radiating directions (well displayed in photo 2) of the texture in a pattern similar to colloform texture

form structure, such as Schalenblende or in various "gel"-1ike or amorphous minerals, such as melnikovite (see Ivanov et al., 1960). Moreover, its size and chemical similarity with large alkali ions is consistent with its extraction from solutions by adsorption processes (Albuquerque and Shaw, 1972).

The similarities between the picture of the Tl distribution which is obtained under the ion microprobe and colloform texture is striking and strong1y suggests that adsorption on colloids is the mechanism which controls the behaviour of $\mathrm{T} 1$. This is not in agreement with Roedder's view (1968), in which colloform texture cannot be formed by material in a colloidal state when deposited, but by direct crystallization from a fluid. We however believe that 


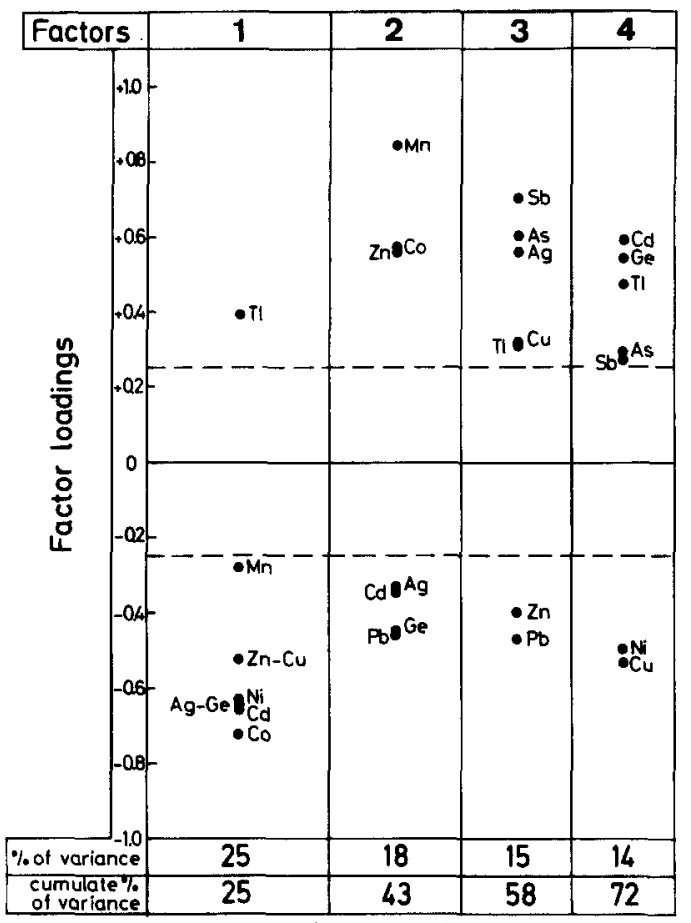

Fig. 2. Graphical representation of the principal component analysis of the trace element contents of iron sulfides from $\mathrm{Pb}-\mathrm{Zn}$ vein deposits. Factor loadings less than 0.22 , below the level of significance following Harman

(1967), are not represented

our factor 1 is an indication that two different mechanisms play a role in the deposition of the iron sulfides and that, all things being equal, the T1 content of a sample is a measure of the relative importance of sorption effects in the process of formation of the particular sample.

Factor 3 groups together S-As-Ag and is also loaded with $\mathrm{Cu}$ and $\mathrm{T} 1$. We interpret this as due to inclusion of trace minerals of sulfosalts, some of them containing $\mathrm{T} 1$, which is known to have geochemical affinities with $\mathrm{Sb}$ and $\mathrm{As}$ (Jankovic and Le Bel, 1976).

Factor 2 is positively loaded with $\mathrm{Mn}$ and $\mathrm{Zn}$ and negatively with $\mathrm{Pb}-\mathrm{Ag}-\mathrm{Cd}-$ $\mathrm{Ge}$. Factor 4 groups $\mathrm{Tl}$ with $\mathrm{Cd}-\mathrm{Ge}$ which are opposed to $\mathrm{Ni}-\mathrm{Cu}$, and might indicate the influence of inclusions of blende which can be rich in Tl (Evrard, 1945) and in Ge-Cd.

Factor 2 is difficult to interpret. It probably results from the combination of several mechanisms. Mn might come from inclusions of blende. It is however hard to understand why $\mathrm{Mn}$, which could easily substitute for $\mathrm{Fe}$, is mainly controlled here by its substitution with $\mathrm{Zn}$ and also why $\mathrm{Cd}-\mathrm{Ge}$, classically diadochic of $\mathrm{Zn}$ (see factor 4) appears here with factor loadings of sign different from $\mathrm{Zn}$. The grouping of $\mathrm{Pb}$ with $\mathrm{Ag}$ is classical in galena and might also indicate inclusions of trace amounts of this mineral.

Though some points are still somewhat obscure, principal component ana1ysis clearly shows that several possible mechanisms can account for the presence of Tl in the population: sorption phenomena and inclusions of sulfosalts and also possibly of blende. This is in agreement with the modes of occurrences of $\mathrm{Tl}$ observed under the ion microprobe and in conformity with what is known of its chalcophilic behaviour.

\section{SOURCE OF THALLIUM: AN OPEN QUESTION}

Polymetallic deposits which show the highest amount of $\mathrm{Tl}$ are related to acidic magmatism either volcanic or plutonic such as in the classical region of Caucasus (Ivanov et al., 1960) or in Turkey (Jankovic and Le Bel, 1976). The enrichment of $\mathrm{T} 1$ in the late stages of the magmatic differentiation is well in agreement with its similarity of behaviour with $\mathrm{K}$.

The source of $\mathrm{T} 1$ in $\mathrm{Pb}-\mathrm{Zn}$ deposits in carbonate environment is however a debatable question. In the Meggen deposit (Westphalia), the distribution of $\mathrm{T} 1$ in and around the stratiform ore body is considered to be due to the exhalative origin of the elements (Thein, 1975; Gwosdz and Krebs, 1977) and can thus be linked to a syn-sedimentary event. In Belgium however, except for some thin K-bentonites of Dinantian age (Thorez and Pirlet, 1979), volcanic rocks are not known interbedded in the Variscan sedimentary pile. In the area, 
acidic plutonism is restricted to the small granitoids of La Helle and Lammersdorf (Germany) (Corin, 1965). They are situated far away from important deposits, such as the Vedrin Mine, and since they have suffered a deformation of Variscan or Caledonian age, they are certainly older than the post-Variscan tectonic event which controls the emplacement of the veins. The presence of a granitic batholith at depth under the Ardennes has been surmised by Fourmarier (in Dewez and Lespineux, 1947) to account for the distribution of the Belgian ore deposits. But no evidence in favour of such an hypothesis has ever been put forward.

$\mathrm{T} 1$, if not magmatic, must find its source in sedimentary rocks from which it was scavenged by hydrothermal brines. When taking the data of Heinrichs et a1. (1980) on sedimentary rocks, it is noted that the $\mathrm{Tl}$ content (average: $0.41 \mathrm{ppm}$; black shales: $2.5 \mathrm{ppm}$ ) is high relative to the $\mathrm{Pb}$ content (average: $16.7 \mathrm{ppm}$, black shales: $82 \mathrm{ppm})$. The $\mathrm{T} 1 / \mathrm{Pb}$ ratio varies between $1 / 50$ and $1 / 30$, values which are higher than those commonly found in sulfides from $\mathrm{Pb}-\mathrm{Zn}$ deposits. Therefore it is not unlikely that any process which would extract and concentrate $\mathrm{Pb}$ would also be active for Tl.

\section{CONCLUSIONS}

Distribution of trace elements in various occurrences of iron sulfides indicates:

1. The iron sulfides related to Belgian $\mathrm{Pb}-\mathrm{Zn}$ vein deposits, mainly in carbonate environment, belonging to different geological units (Namur Synclinorium, Dinant Synclinorium, Vesdre Massif) or situated in Devonian or Dinantian strata, form a group along with two occurrences from the Cévennes border; this group can be distinguished from iron sulfides of various origins by their $\mathrm{Ni}$, Co and $\mathrm{T} 1$ contents. Their $\mathrm{Co}$ : Ni ratio $(<1)$ can be compared with sedimentary occurrences but is distinctly lower than in high temperature occurrences ( $\mathrm{Co}: \mathrm{Ni}>1$ ). Their Tl content ( $>30 \mathrm{ppm}$ up to $0,6 \%)$ permits to distinguish them from all other occurrences ( $\mathrm{T} 1<10 \mathrm{ppm}$ ). The Co content is lower than in sedimentary occurrences.

2 . The mode of occurrence of $T 1$ in iron sulfides is either in the form of trace minerals or is dispersed in the iron sulfide phase according to a zoned and recurrent pattern, similar to a colloform texture. Several lines of evidence indicate that sorption phenomena and inclusions of sulfo-salts can account for most of the behaviour of this element in the deposition of the iron sulfides.

3. The paucity of acidic magmatism in Belgium during Devonian and Carboniferous sedimentation or in post-Variscan times makes the hypothesis of a magmatic source for the Tl difficult to accept. The hypothesis that T1 together with other elements was scavenged from sedimentary rocks by hydrothermal solutions is favoured.

Acknowledgements. The present investigation is part of a research program supported by the EEC (111-79-7-MPPB) and the Belgian SIPS (MP-CE-5) (Project Leaders: P. Evrard and J. Belliere). The authors wish to express their gratitude to the Union Minière, for giving access to drilled samples of Poppelsberg, Stuck and Lontzen; to L. Dejonghe, A.M. Fransolet and F. Dimanche for donating various samples; and to R. Gijbels for the use of the SIMS instrument and for interesting discussions.

\section{REFERENCES}

Ahrens, L.H., Taylor, S.R.: Spectrochemical analysis (2nd Ed) AddisonWesley, 454 p (1961)

Albuquerque de, C.A.R., Shaw, D.M.: Thallium. In: "Handbook of Geochemistry". Wedepoh1, K.H. (ed) Springer, Berlin. Vol. II-5 section 81,1972 Aubagne, M., Leleu, M.: Recherche de guides de prospection pour les gites $\mathrm{Pb}-\mathrm{Zn}$ liés aux strates en environnement carbonaté. Deuxième phase: Le gite de la Croix de Pallières (Bor- 
dure Cevenole, Gard), B.R.G.M.Compte rendu de fin d'étude, 1981

Bernard, A.: Contribution à l'étude de la province métallifère sous-Cévenole. Sci. Terre, 7, 3-4, 123-403 (1961)

Bernard, A.: Comments on "Présence de thallium dans les sulfures de fer de la mine de Pallière (Gard, France)" by J.C. Duchesne. Ann. Soc. Geol. Belgique 88, 151-152 (1965)

Bralia, A., Sabatini, G., Troja, F.: A reevaluation of the $\mathrm{Co} / \mathrm{Ni}$ ratio in pyrite as geochemical tool in ore genesis problems. Miner. Deposita, $14,353-374$ (1979)

Christie, O.H.J.: Three trace element geological materials certified as a result of a cooperative investigation. Talanta, 22, 1048-1050 (1975)

Corin, F.: Atlas des roches éruptives de Belgique. Mém. Expl. Cartes Géol. et Min. de Belgique, no 4, 190 p, 1965

Currie, L.A.: Limits for qualitative and quantitative determination. Anal. Chemistry, 40, 586-592 (1968)

Davis, J.C.: Statistics and data ana $1-$ ysis in Geology. John Wiley, $420 \mathrm{p}$, 1973

Dejonghe, L.: Discovery of a sedimentary $\mathrm{Ba}$ ( $\mathrm{Fe}, \mathrm{Zn}, \mathrm{Pb}$ ) ore body of Frasnian age at Chaudfontaine, Province of Liège, Belgium. Mineral. Deposita, 14, 15-20 (1979)

Dewez, L., Lespineux, G.: Les minerais du sol belge. In: "Centenaire de I'A.I.Lg - Congrès 1947 Section Géologie". Ed. AILg, Iiège, 73-120 (1947)

Dillen, H., Gijbels, R.: Etude de que1ques éléments en traces dans la pyrite par analyseur ionique. J. Microsc. Spectrosc. Electron., 6, 179-194 (1981)

Duchesne, J.C.: Présence de tha1lium dans les sulfures de fer de la mine de Pallière (France). Ann. Soc. Géol. Be1gique, 87, 1-7 (1964)

Duchesne, J.C.: A reply to A. Bernard's comments on "Présence de tha11ium dans les sulfures de fer de la mine de Pallière (Gard, France)". Ann. Soc. Géol. Belgique, 88, 153-155 (1965)

Evrard, P.: La minéralisation de Vedrin (Province de Namur, Belgique). Ann.
Soc. Géol. Belgique, 66, M181-202 (1943)

Evrard, P.: Minor elements in sphalerites from Belgium. Econ. Geol. 40, 568-574 (1945)

Gwosdz, W., Krebs, W.: Manganese halo surrounding Meggen ore deposit, Germany. Trans. Inst. Min. Metal., sect. $\mathrm{B}, 86,73-77$ (1977)

Harman, H.H.: Modern factor analysis (2nd ed) University of Chicago Press, 1967

Hegemann, F., Leybold, C.: Eine Me thode zur quantitativen spektrochemischen Analyse von Pyrit. Zeitschr. Erzbergbau u. Metal1hüttenwesen, v. 7, 108-113 (1954)

Heinrichs, H., Schulz-Dobrick, B., Wedepoh1, K.H.: Terrestrial geochemistry of $\mathrm{Cd}, \mathrm{Bi}, \mathrm{Tl}, \mathrm{Zn}$ and $\mathrm{Rb}$. Geochim. Cosmochim. Acta 44, 1519-1533 (1980)

Ivanov, V.V., Volgin, V.Y., Krasnov, A.A., Lizunov, N.V.: Thallium: Basic geochemical and mineralogical properties, genetic types of deposits and geochemical provinces (in Russian), Moscow Academy of Sciences, Trans 1. International Geology Review, Booksection. Published by the American Geological Institute, 1960

Jankovic, S., Le Bel, L.: Le tha1lium dans le minerai de Bözcukur près Kitahya, Turquie. Bull. Suisse Minéral. Pétro1. 56, 69-77 (1976)

Loftus-Hi1ls, G., Solomon, M.: Cobalt, Nickel and Selenium in sulfides as indicators of ore genesis. Mineral. Deposita, 2, 228-242 (1967)

Robinson, P., Walshe, J.L.: Trace-element analysis of pyrite - an interlaboratory survey. Trans. Inst. Min. Meta1. 5, B216-218 (1977)

Roedder, E.: The noncolloidal origin of "co11oform" textures in sphalerite ores. Econ. Geol. 63, 451-471 (1968)

Shal, K.: Thallium. In: Handbook of Geochemistry. Wedepoh1, K.J. (ed) vol. II-5 section $81 \mathrm{~A}$. Springer, Ber1in, Heidelberg, New York, 1974

Schrön, W., Rossler, H.J.: Drei neue geochemisch-mineralogische Komplexstandards Galenit GF-1, Sphalerit SF-1 and Pyrit PS-1. Z. Angewandte Geologie, 21, 17-25 (1975) 
Shaw, D.M.: The geochemistry of tha1Iium. Geochim. Cosmochim. Acta, 2, $118-154(1952)$

Stoiber, R.E.: Minor elements in sphalerites. Econ. Geol. 35, 501-519 (1940)

Thein, J.: Geochemische Untersuchungen im Sulfiderz im Nebengestein und in den Böden der Lagerstätte Meggen-Westfalen. Doctorate thesis - Rheinische Friedrich-Wi thelms-Universität $z u$ Bonn, $70 \mathrm{p}$ (unpublished), 1975

Thorez, J., Pirlet, H.: Petrology of $\mathrm{K}$-Bentonite beds in the carbonate series of the Visean and Tournaisian stages of Belgium. In: "Intern. Clay Conference 1978", Mortland \& Farmer (eds), Elsevier, 323-332 (1979)

Received: October 7, 1982

Accepted: January 4, 1983

Prof. J.C. Duchesne

Laboratoires associés de Géologie, Pétrologie et Geochimie, Université de Liège B-4000 Sart-Tilman Belgique 